\title{
Toads Bufo spp. in the diets of mustelid predators in Belarus
}

\author{
Vadim E. SIDOROVICH and Mikhail M. PIKULIK
}

\begin{abstract}
Sidorovich V. E. and Pikulik M. M. 1997. Toads Bufo spp. in the diets of mustelid predators in Belarus. Acta Theriologica 42: 105-108.

Amphibians were important prey to the European mink Mustela lutreola, the American mink $M$. vison, polecat $M$. putorius, river otter Lutra lutra, and badger Meles meles, and formed a minor component of the food taken by stoat Mustela erminea, weasel $M$. nivalis, and pine marten Martes martes. Mink and otter strongly selected for frogs Rana spp. and avoided toads Bufo spp. However, the common toad can be an important prey for semiaquatic mustelids under unfavourable feeding conditions. Toads (mainly Bufo bufo, and rarely B. viridis) also occurred in significant numbers in the diets of polecats and badgers, which seemed to prey on frogs and toads with no clear selection.
\end{abstract}

Institute of Zoology, Academy of Sciences of Belarus, F. Skoriny str. 27, Minsk-220072, Belarus

Key words: diet, Mustelidae, Bufo, amphibians, foraging behaviour of otters

\section{Introduction}

In Europe amphibians are important prey to the European mink Mustela lutreola, the American mink Mustela vison, the otter Lutra lutra, and the polecat Mustela putorius (Teplov 1953, Tumanov and Smelov 1980, Weber 1989, Weber 1990, Pikulik and Sidorovich 1991, Sidorovich 1992, Brzeziński et al. 1993, Dunstone 1993, Sidorovich et al., in press). However, most amphibians taken by predators are frogs Rana sp., whereas toads, due to their poisonous dermal secretion, are usually avoided (Weber 1990). In Belarus, toads, especially the common toad Bufo bufo, are very abundant amphibians (Pikulik 1985) but, according to our preliminary study, semiaquatic mustelids eat toads rarely (Pikulik and Sidorovich 1991). The purpose of this note was to evaluate the role of toads as prey to various mustelid species in Belarus.

\section{Material and method}

In the period 1992-1995, a total of 5934 scats of stoat Mustela erminea, weasel Mustela nivalis, polecat, European mink, American mink, otter, badger Meles meles, and pine marten Martes martes were analysed (Table 1). Amphibians were identified by the recognisable bones (Bohme 1977, März 1987) recovered from the scats. The scats were collected only in situations when we could identify the species that deposited them (from tracks, livetrapping, specific odour in the case of otters scats, and 
occasionally by visual observations). Basically, we investigated mustelid predation on toads and frogs in various seasons and in various types of ecosystems (banks and floodplains of different size rivers, shores of glacial lakes, small streams, forests, bogs, meadows, fields, villages). The main study areas are located in the following districts of Belarus: Gorodok, Rossony, Minsk, Smolevichy, Borisov, Naropvlya.

\section{Results and discussion}

The occurrences of toads and frogs in the diets of mustelids are presented in Table 1. Frogs were important prey to American mink, otter, polecat, and badger. These species also consumed toads, but always in smaller quantities. Other researchers (Weber 1990, Brzeziński et al. 1993, Dunstone 1993) obtained similar results regarding the proportion of toads in diets of semiaquatic mustelids. Toads (mainly Bufo bufo, and rarely B. viridis) formed $36 \%$ of all amphibians taken by the polecat (Table 1). Similar results were obtained in polecat by Weber (1989) in Switzerland. In the badgers' diet, toads comprised $42 \%$ of all amphibians taken (Table 1).

According to Pikulik (1985), the ratio of toad to frog abundance in various ecosystems and regions of Belarus varies from 1:1 in some forest habitats or village enviroments to 1:12 in other forests or wetlands. The ratios of toad to frog numbers in the diets of mink and otter are much lower and vary from 1:46 to 1:301. There are significant differences between the ratios of toads and frogs in the ecosystems and the mustelid diets $\left(\chi^{2}=6.42, p<0.01\right)$. This result suggests that there is a strong avoidance of toads by semiaquatic mustelids feeding on amphibians. These species probably prefer frogs because toads have poisonous dermal secretion. Polecats and badgers seem to prey on amphibians unselectively. The ratios of toad and frog numbers in their diets (1:1.8 and 1:1.4, respectively) are close to that in the ecosystems.

Table 1. Toads Bufo spp. and frogs Rana spp. in the diets of mustelid predators in Gorodok, Rossony, Minsk, Smolevichy, Borisov, and Naropvlya districts of Belarus, 1992-1995.

\begin{tabular}{|c|c|c|c|c|c|c|c|c|}
\hline Parameter & $\begin{array}{l}\text { Mustela } \\
\text { erminea }\end{array}$ & $\begin{array}{l}\text { Mustela } \\
\text { nivalis }\end{array}$ & $\begin{array}{l}\text { Mustela } \\
\text { putorius }\end{array}$ & $\begin{array}{l}\text { Mustela } \\
\text { lutreola }\end{array}$ & $\begin{array}{c}\text { Mustela } \\
\text { vison }\end{array}$ & $\begin{array}{l}\text { Lutra } \\
\text { lutra }\end{array}$ & $\begin{array}{l}\text { Meles } \\
\text { meles }\end{array}$ & $\begin{array}{l}\text { Martes } \\
\text { martes }\end{array}$ \\
\hline Number of scats & 65 & 43 & 618 & 974 & 2087 & 1948 & 87 & 99 \\
\hline \multicolumn{9}{|c|}{ Percentage of scats with bone remains of: } \\
\hline toads & - & - & 23.6 & 0.4 & 1.5 & 0.3 & 13.8 & - \\
\hline frogs & 7.7 & 2.3 & 38.8 & 87.3 & 66.1 & 64.6 & 19.5 & 7.1 \\
\hline$n$ of prey specimens & 81 & 50 & 1009 & 1725 & 3871 & 5182 & 366 & 212 \\
\hline \multicolumn{9}{|c|}{ Percentage of amphibians in the total number of prey specimens: } \\
\hline toads & - & - & 14.5 & 0.2 & 0.8 & 0.1 & 3.3 & - \\
\hline frogs & 6.2 & 2.0 & 25.7 & 50.3 & 36.9 & 30.1 & 4.6 & 3.3 \\
\hline Toad : frog ratio & - & - & $1: 1.8$ & $1: 251.5$ & $1: 46.1$ & $1: 301.0$ & $1: 1.4$ & - \\
\hline
\end{tabular}


An interesting case that illustrated the role of toads in feeding ecology of otters was observed in April 1995 at the Łutownia river in the Białowieża Primeval Forest, eastern Poland. On that river, otters usually feed on the common frog Rana temporaria. In 1993-1995, 100\% of otter scats collected over the winter season $(n=117)$ contained bones of the common frog, and $88 \%$ of scats collected in other seasons except for April $1995(n=295)$ contained frog bones; whereas common toad bones were found in otter scats only once (in June). The beginning of April 1995 was warm and most of common frogs left the river and went to their spawning pools located in the bog alderwoods (Alnus glutinosa stands). However, it was abnormally cold in mid and late April and common frogs delayed spawning. Spawning common frogs are very important prey to the otter in the flood period when availability of fish decreases (Pikulik and Sidorovich 1991). This is especially evident on small rivers characterized by low abundance of fish. Therefore, we expected that, in April 1995, otters inhabiting the Łutownia river would intensively prey on common toads concentrated at the river for spawning. In fact, during one day of census on $5.8 \mathrm{~km}$ of the river we discovered 49 common toads skinned by otters near the places where toads were concentrated. Those places were substantially marked with otter spraints. We found only few signs of other predators close to those places. The otter spraints analysed $(n=40)$ contained bones of common toads $(57.5 \%)$, common frogs $(67.5 \%)$ and fish remains $(15.0 \%)$. This observation evidences that toads can be an important prey for otters under unfavourable feeding conditions.

\section{References}

Brzeziński M., Jędrzejewski W. and Jędrzejewska B. 1993. Diet of otters (Lutra lutra) inhabiting small rivers in the Białowieża National Park, eastern Poland. Journal of Zoology, London 230: 495-501.

Bohme G. 1977. Zur Bestimmung quartarer Anuren Europas an Hand von Skelettelementen. Wissenschaftliche Zeitschrift der Humboldt-Universität zu Berlin, Math. Nat. R. 26: 283-300.

Dunstone N. 1993. The mink. T \& AD Poyser Ltd., London: 1-232.

März R. 1987. Gewoll- und Rupfungskunde. Akademie Verlag, Berlin: 73-79.

Pikulik M. M. 1985. [Amphibians in Belarus.] Nauka i Teknika, Minsk: 1-190. [In Russian]

Pikulik M. M. and Sidorovich V. E. 1991. [Estimation of structure-functional relationships of populations of semiaquatic predators and amphibians in Belarus.] Ecologiya (Sverdlovsk) 6: 28-36. [In Russian]

Sidorovich V. E. 1992. Comparative analysis of the diets of European mink (Mustela lutreola), American mink (M. vison) and Polecat (M. putorius) in Byelorussia. Small Carnivore Conservation. 6: $2-4$.

Sidorovich V. E., Kruuk H., Macdonald D. W. and Maran T. (in press). Diets of semi-aquatic carnivores in northern Belarus, with implications for population changes. [In: Behaviour and ecology of riparian mammals. N. Dunstone and M. L. Gorman, eds]. Symposia of the Zoological Society of London.

Teplov V. P. 1953. [Otter in Pechoro-Ilich Reserve]. Byulleten Moskovskogo Obshchestva Ispytatelei Prirody, Otdel Biologicheskiï 58(6): 7-16. [In Russian] 
Tumanov I. L. and Smelov V. A. 1980. Feeding relationships of mustelids in the north-western Russia. Zoologicheskiï Zhurnal 59: 1536-1544. [In Russian with English summary]

Weber D. 1989. The diet of polecats (Mustela putorius L.) in Switzerland. Zeitschrift für Säugetierkunde 54: 157-171.

Weber J.-M. 1990. Seasonal exploitation of amphibians by otters (Lutra lutra) in north-east Scotland. Journal of Zoology, London 220: 641-651.

Received 6 September 1996, accepted 13 January 1997. 